\title{
Analysis by Transformation of the Penicillinase System in Bacillus licheniformis
}

\author{
By D. J. SHERRATT* AND J. F. COLLINS \\ Department of Molecular Biology, University of Edinburgh, Edinburgh, \\ EH9 $3 J R$, Scotland
}

(Received 22 June 1972; revised 3 January 1973)

S UMMAR Y

The penicillinase locus is weakly linked to the ilvA and ilvD loci in Bacillus licheniformis. Transformants for these markers include up to $5 \%$ of transformants for the penicillinase locus. Penicillinase mutants have been mapped in the structural gene and at least two regulatory genes. One regulatory gene is $90 \%$ linked to the structural gene, a second regulatory gene is $50 \%$ linked to the first regulatory gene. Another possible regulatory gene is unlinked to the others. Mutations in the first regulatory gene show it has a negative control function; the other regulatory mutations result in defective inducibility though the role of the gene products is not known. A model for the regulation of penicillinase synthesis in this organism is discussed.

\section{INTRODUCTION}

Penicillinase has long been known as an inducible enzyme in the Gram-positive organisms Bacillus cereus (Pollock, 1950), B. licheniformis (Duthie, 1947) and Staphylococcus aureus (Geronimus \& Cohen, 1957). In each case the inducer of penicillinase appears to exert its effect at the surface of the cell, and when the inducer is penicillin, some of it becomes irreversibly attached to the cell surface. The synthesis of penicillinase accelerates slowly over a period of 15 to 60 min before reaching its maximum response. The nature of the key events by which an inducer interacts with a cell and causes derepression of the penicillinase genes is not understood.

Dubnau \& Pollock (1965) reported that genetic analysis was possible in the Bacillus licheniformis system, through the transformation of strain 749 , though the frequency obtained was very low. No simple method existed for obtaining large numbers of penicillinase transformants, though penicillinase-positive transformants could be selected from a background of mutant penicillinase-negative organisms. Evidence for recombination within the structural gene was obtained, together with data showing close linkage between the structural gene and a regulator gene which appeared to exert negative control.

With the description of a high-frequency transformation system in Bacillus licheniformis ATCC 9954A (Thorne \& Stull, I966) it seemed that a further analysis might be attempted; preliminary work carried out by J. Fleming and P. Hill (unpublished) showed that the penicillinase produced by strain 9945A was enzymatically and immunologically indistinguishable from that produced by strain 749 . Penicillinase markers in strain 749 were found to be transferrable by transformation into strain $9945 \mathrm{~A}$; and in this paper some of the mutants characterized by Dubnau \& Pollock (1965) have been analysed genetically by this method.

* Present address: School of Biological Sciences, The University of Sussex, Falmer, Brighton, Sussex. 


\section{METHODS}

Organisms. Bacillus licheniformis ATCC 9945A and its derivatives MI7-RI (pep ade-I) and MI9 (pep met-I) were obtained from Professor C. B. Thorne (Department of Microbiology, University of Massachusetts). The rough colonial variants (pep) of strain ATCC 9945A act as good recipients in transformation experiments (Thorne \& Stull, 1966); most strains used were derived from MI7-RI. The mutants of B. licheniformis 749 used (Table I) were originally described by an isolation number (Dubnau \& Pollock, 1965); for clarity the description has been changed to include designation of the parent strain. Thus Pen 22 (Dubnau \& Pollock, I965) is described here as 749/1 Io pen $\mathrm{C}_{3} / 22$.

Media. Transformation media (BLSG and TM) were those of Thorne \& Stull (1966). The minimal medium used contained (per 1): $\mathrm{K}_{2} \mathrm{HPO}_{4}, \mathrm{I} 4.65 \mathrm{~g} ; \mathrm{KH}_{2} \mathrm{PO}_{4}, 5.5 \mathrm{~g} ;\left(\mathrm{NH}_{4}\right)_{2} \mathrm{SO}_{4}$, $2 \mathrm{~g}$; sodium citrate, $2 \mathrm{H}_{2} \mathrm{O}, 3 \mathrm{~g} ; \mathrm{MgSO}_{4} \cdot 7 \mathrm{H}_{2} \mathrm{O}, 0.2 \mathrm{~g} ; \mathrm{FeCl}_{3} \cdot 6 \mathrm{H}_{2} \mathrm{O}, 40 \mathrm{mg} ; \mathrm{MnSO}_{4} . \mathrm{H}_{2} \mathrm{O}$, $0.5 \mathrm{mg}$; glucose, $2 \mathrm{~g}$; thiamine $\mathrm{HCl}$, I $\mathrm{mg}$; sodium L-glutamate, $0.5 \mathrm{~g}$; L-aspartic acid, $0.25 \mathrm{~g}$; glycine, $0.15 \mathrm{~g}$. Iron and manganese, glucose, thiamine and the three amino acids were added sterilely to the remaining salt solution. Where appropriate, amino acids were added as supplements at $20 \mathrm{mg} / \mathrm{l}$; adenine sulphate at $10 \mathrm{mg} / \mathrm{l}$; thymine at $100 \mathrm{mg} / \mathrm{l}$; streptomycin sulphate at I $\mathrm{g} / \mathrm{l}$. L-broth contained $(\mathrm{g} / \mathrm{l}): \mathrm{NaCl}$, Io; yeast extract, 5 ; and Difco tryptone, ro. Sporulation medium (P. Hill, unpublished), used for the preparation of spore stocks in high yield, contained (per 1): Difco potato extract, $10 \mathrm{~g}$; Casitone, Io g; yeast extract, $2 \mathrm{~g}$; and special salts solution, $2 \mathrm{ml}$ (Collins \& Kornberg, I960).

Mutagenesis. Ultraviolet radiation. About $\mathrm{I}^{8}$ spores in distilled water $(3 \mathrm{ml})$ were irradiated in a Petri dish for $30 \mathrm{~s} 30 \mathrm{~cm}$ from a I $50 \mathrm{~W}$ u.v. lamp (Hanovia, Slough, Buckinghamshire). Survival was about I \%; irradiated spores were either diluted into L-broth and grown up before plating or plated directly on to a solid rich medium.

$N$-Methyl- $N^{\prime}$-nitro- $N$-nitrosoguanidine ( $N T G$ ) treatment. An exponentially growing culture in L-broth was diluted I/20 into TM and incubated for $45 \mathrm{~min}$. NTG $(20 \mu \mathrm{g} / \mathrm{ml})$ was added, and the incubation continued for 20 to $60 \mathrm{~min}$. The organisms were harvested and regrown in L-broth for 2 to $\mathrm{I} 2 \mathrm{~h}$, then plated for the detection of mutants.

Hydroxylamine treatment (after Tessman, 1968). A suspension of $10^{8}$ spores in $\mathrm{I} \mathrm{ml}$ water was treated with $5 \mathrm{ml}$ hydroxylamine solution $\left(2 \mathrm{M}-\mathrm{NH}_{2} \mathrm{OH} . \mathrm{HCl}\right.$ neutralized with $2 \mathrm{~N}$ $\mathrm{NaOH})$ at $35{ }^{\circ} \mathrm{C}$ for $24 \mathrm{~h}$. The spores were collected by centrifugation and washed twice with $2 \%(\mathrm{v} / \mathrm{v})$ acetone in water to destroy residual hydroxylamine. Survival was $10 \%$.

Nitrous acid treatment of $D N A$. A DNA solution ( $\mathrm{I} \mathrm{ml}$ ) from a prototroph was incubated with $0.2 \mathrm{ml} 2 \mathrm{M}-\mathrm{NaNO}_{2}$ and $0.2 \mathrm{ml} 2 \mathrm{M}$-sodium acetate buffer, $\mathrm{pH} 4.2$, at $35^{\circ} \mathrm{C}$ for $\mathrm{I} \cdot 5 \mathrm{~h}$. More than $95 \%$ of the transforming ability was lost after this treatment.

Detection of mutants. Auxotrophic mutants were detected by replica plating techniques or by appropriate selection techniques. A thymine-requiring mutant (thy-I) was made by the method of Okada, Homma \& Sonohara (I962) and selected by its resistance to aminopterin $(100 \mu \mathrm{g} / \mathrm{ml})$ in the presence of thymine $(100 \mu \mathrm{g} / \mathrm{ml})$ in minimal medium. For selection of specific auxotrophs, an enrichment technique was used, using D-cycloserine instead of penicillin (Curtiss, Charamella, Berg \& Harris, 1965). Penicillin selection is difficult in Bacillus licheniformis because of the strong co-operative protection afforded by the exocellular penicillinase produced.

Transformation. The procedure used was a modification of that of Thorne \& Stull (I966). Recipient cultures were grown from a small spore inoculum (about $10^{6}$ spores) in BLSG medium $(25 \mathrm{ml})$ in an Erlenmeyer flask $(250 \mathrm{ml})$. The culture was incubated for $18 \mathrm{~h}$ on an orbital shaker $(280 \mathrm{rev} . / \mathrm{min})$ at $37^{\circ} \mathrm{C}$. The stationary-state culture was diluted $\mathrm{I} / 30$ into 


\section{Table I. Penicillinase mutants of Bacillus licheniformis 749 \\ (data adapted from Dubnau \& Pollock, 1965)}

Genotypes given are based on the phenotypes and on the results of crosses given in this paper. CRM test (Pollock 1964): precipitation by specific antiserum in Ouchterlony plate test (no inducer present during growth of the organisms).

\begin{tabular}{|c|c|c|c|c|}
\hline \multirow[b]{2}{*}{ Description } & \multicolumn{2}{|c|}{ Penicillinase activity* } & \multirow{2}{*}{$\begin{array}{l}\text { CRM } \\
\text { reaction }\end{array}$} & \multirow{2}{*}{$\begin{array}{l}\text { Probable pen } \\
\text { genotype }\end{array}$} \\
\hline & Uninduced & Induced & & \\
\hline 749 & 20 & 1000 & - & $I^{+} P^{+}$ \\
\hline \multicolumn{5}{|l|}{749 pen 9} \\
\hline At $30^{\circ} \mathrm{C}$ & 20 & I 200 & - & $I_{9} P^{+}$ \\
\hline At $47^{\circ} \mathrm{C}$ & 400 & 1400 & N.T. & \\
\hline 749 pen $\mathrm{C}$ & 3000 & 3000 & + & IC $P^{+}$ \\
\hline 749 pen $\mathrm{c} / 7 \mathrm{I}$ & 50 & 52 & + & $I_{\mathrm{C}} P_{7 \mathrm{I}}$ \\
\hline 749 pen $\mathrm{c} / 72$ & $<0.05$ & $<0.05$ & + & IC $P_{72}$ \\
\hline $749 /$ I $10($ his-I str-I) & 20 & 1000 & - & $\mathrm{I}^{+} \mathrm{P}^{+}$ \\
\hline $749 /$ I 10 pen 14 & 20 & 400 & - & $R \mathrm{I} 4 \mathrm{I}^{+} \mathrm{P}^{+}$ \\
\hline 749/1 I O pen 27 & 15 & 130 & - & $R 27 I^{+} P^{+}$ \\
\hline 749/1 IO pen 28 & 24 & 23 & - & $R 28 P^{+}$ \\
\hline 749/I IO pen 3I & 9 & 10 & - & $R_{3 I} I^{+} P_{3 I}$ \\
\hline $749 / 110$ pen 32 & 208 & 208 & + & $R 32 P^{+}$ \\
\hline 749/1 IO pen C3 & 3700 & 4000 & + & IC3 $P^{+}$ \\
\hline $749 / 1$ IO pen $\mathrm{C} 3 / 16$ & $3 \cdot 8$ & $2 \cdot 6$ & + & IC $P$ I 6 \\
\hline 749/I IO pen $\mathrm{c} 3 / \mathrm{I} 7$ & $2 \mathrm{I}$ & 25 & - & $I_{1} 3 P_{17}$ \\
\hline $749 / 110$ pen $\mathrm{C} 3 / 19$ & 90 & 90 & + & IC3 PI9 \\
\hline $749 / 1$ I o pen $\mathrm{C} 3 / 20$ & 33 & 24 & + & $I_{C} P_{2 O}$ \\
\hline $749 / 1$ 1 0 pen $\mathrm{C} 3 / 22$ & $<0.05$ & $<0.05$ & + & $I_{C} P_{22}$ \\
\hline $749 /$ I IO pen $\mathrm{C} 3 / 23$ & 4250 & N.T. & $\begin{array}{c}+ \text { (thermolabile } \\
\text { enzyme })\end{array}$ & $I_{C} P_{23}$ \\
\hline $749 /$ I IO pen $\mathrm{c} 3 / 25$ & $2 \cdot 8$ & $2 \cdot I$ & - & $I_{\mathrm{C}} P_{25}$ \\
\hline $749 /$ I IO pen $\mathrm{C} 3 / 26$ & 0.8 & 0.9 & - & $I_{C 3} P_{26}$ \\
\hline
\end{tabular}

TM ( $\mathrm{I}$ to $2 \mathrm{ml}$ ) in a test tube, followed immediately by the addition of a DNA solution (I $\mu \mathrm{g} \mathrm{DNA} / \mathrm{ml}$ was found to be a saturating concentration). After incubation at $37^{\circ} \mathrm{C}$ for I5 to $60 \mathrm{~min}$ on a reciprocal shaker ( $5 \mathrm{~cm}$ stroke, I00 strokes/min), transformation was stopped by the addition of DNase $(40 \mu \mathrm{g} / \mathrm{ml})$ I $5 \mathrm{~min}$ before plating on to solid selective media; transformants were scored after incubation of the plates for 40 to $48 \mathrm{~h}$ at $37{ }^{\circ} \mathrm{C}$. DNA from strain 749 was found to be as effective as DNA from strain 9945A in repairing the auxotrophs of strain 9945A tested.

DNA preparation. DNA for transformation was prepared by the method of Marmur (I96I), omitting the treatment with ribonuclease; the DNA was stored in $2 \mathrm{M}-\mathrm{NaCl}$, over chloroform, at $4{ }^{\circ} \mathrm{C}$. Crude lysates of culture were also used as sources of DNA. Salinecitrate $(\mathrm{I} \cdot 5 \mathrm{M}-\mathrm{NaCl}+0.15 \mathrm{M}$-trisodium citrate) $(\mathrm{I} \%, \mathrm{v} / \mathrm{v})$ was added to a late exponential phase culture in L-broth, and the culture was frozen and thawed three times. After overnight autolysis at $4{ }^{\circ} \mathrm{C}$ the culture was spun at $10000 \mathrm{rev} . / \mathrm{min}$ for $30 \mathrm{~min}$. The supernatant was used in transformation experiments $(0.05 \mathrm{ml}$ lysate $/ \mathrm{ml} \mathrm{TM})$ supplemented with an equal volume of sterile $2 \mathrm{M}-\mathrm{NaCl}$. The donor strains used for this procedure were chosen to be both untransformable (either strain 749 or pep $^{+}$derivatives of 9945A) and unable to grow on the selective media through some auxotrophic mutation.

Penicillinase assays. A modified version (J. F. Collins, unpublished) of the Perret assay (Perret, I954) was used. The sample (up to I $\mathrm{ml}$ ) was incubated with $2.5 \mathrm{ml}$ penicillin solution ( $2.4 \mathrm{mg}$ benzylpenicillin $/ \mathrm{ml}$ in $0 . \mathrm{I} \mathrm{M}$-phosphate buffer, $\mathrm{pH} 7.0$ ) at $30^{\circ} \mathrm{C}$; for the control 
$2.5 \mathrm{ml}$ penicillin solution was incubated alone. After incubation (for up to $\mathrm{I} h$, depending on the sample activity) the reaction was stopped by the addition of $5 \mathrm{ml} 0.16 \mathrm{~N}-\mathrm{I}_{2}$ and $0.06 \mathrm{M}-$ $\mathrm{KI}$ in $2 \mathrm{M}$-sodium acetate buffer, $\mathrm{pH}_{4.2}$; the same amounts of iodine solution and of the sample were added to the control. After Io min to allow the iodine to react with the penicilloic acid, the mixtures were centrifuged for $5 \mathrm{~min}$ at $3000 \mathrm{rev} . / \mathrm{min}$ to sediment the organisms, and the difference in absorbance at $499 \mathrm{~nm}$ was measured in $\mathrm{I} \mathrm{cm}$ cells. This difference is converted into units of penicillinase/ml sample (Pollock, 1960) by multiplying it by the total volume of liquid (in $\mathrm{ml}$ ) in the mixture at the end and correcting to $\mathrm{I} \mathrm{ml}$ of sample and $\mathrm{I} h$ of incubation.

Penicillinase detection on plates. A convenient method of detecting and estimating penicillinase levels on plates was developed by Collins (unpublished). Polyvinyl alcohol (Gelvatol, grade $\mathrm{O}-6 \mathrm{o} \mathrm{G} ;(0.75 \%)$ is incorporated in the usual solid media. Plates are flooded with 5 to $10 \mathrm{ml}$ iodine solution $\left(0.08 \mathrm{~N}-\mathrm{I}_{2}\right.$ in $0.32 \mathrm{~N}-\mathrm{KI}+\mathrm{I} \%(\mathrm{w} / \mathrm{v})$ sodium tetraborate) for 30 to $60 \mathrm{~s}$. A deep-blue $\mathrm{I}_{2}$-PVA complex is formed; the plate is drained, then flooded with a $\mathrm{I} \%(\mathrm{w} / \mathrm{v})$ solution of penicillin in $0 . \mathrm{I}$ M-phosphate buffer, $\mathrm{pH} 7.0$. Penicilloic acid, produced by the action of penicillinase on penicillin, reacts with the iodine and clears the blue colour. The amount of penicillinase is shown by the speed and extent of the clearing reaction. The phenotype of the organism can be judged from the amount of enzyme and the size of the colony, though in crosses the phenotypes are checked by measuring the production of penicillinase in liquid media. This method can distinguish on the plate $749 /$ I I 0 pen $\mathrm{c} 3 / 22$ ( $<0.05$ units/mg), 749/I Io pen $\mathrm{c}_{3} / 26$ (0.8 units/mg), 749 (20 units/mg), 749/I Io pen 32 (208 units/mg) and 749 pen $\mathrm{C}$ (3000 units $/ \mathrm{mg}$ ).

Test of inducibility. Exponentially growing cultures at $0.1 \mathrm{mg}$ dry wt bacteria/ml were induced with $2 \mu \mathrm{g}$ cephalosporin $\mathrm{C} / \mathrm{ml}$. The specific activity of the culture was determined after $2.5 \mathrm{~h}$ of growth, when the culture had reached 0.5 to $\mathrm{I} \cdot 0 \mathrm{mg}$ dry $\mathrm{wt} / \mathrm{ml}$. The difference between the behaviour of the test culture and a similar uninduced control at this time gave a measure of inducibility.

For a qualitative plate test, strains were streaked radially round a $6 \mathrm{~mm}$ well in a plate, to within Io $\mathrm{mm}$ of the well. About $3 \mathrm{mg} \mathrm{7-aminocephalosporanic} \mathrm{acid} \mathrm{was} \mathrm{placed} \mathrm{in} \mathrm{the}$ well after the organisms had grown overnight, and the plate was incubated for $3 \mathrm{~h}$ at $37^{\circ} \mathrm{C}$. The distribution of the penicillinase along the streaks on staining the plates indicated whether or not the strain had induced.

Mapping experiments and strain construction. Standard transformations were used for 2- and 3-factor crosses. Most 749 penicillinase phenotypes were transferred into 9954A recipients for study, and recombinant pen genotypes were also obtained in these experiments. In mapping experiments, penicillinase transformants were scored amongst transformants selected for the repair of the ilvAI, ilvDI or thy-I markers. Phenotypes were confirmed by examination of enzymatic and immunological properties and genotypes by the behaviour of the strain in suitable test crosses.

Materials. Benzyl penicillin, 7-aminocephalosporinic acid, cephalosporin C and streptomycin sulphate were gifts from Glaxo, Ltd, Stoke Poges, Buckinghamshire. D-Cycloserine was obtained from the Sigma Chemical Co. Ltd, London. Aminopterin was obtained from Koch-Light Laboratories, Colnbrook, Buckinghamshire. Deoxyribonuclease-I was obtained from the Worthington Biochemical Corporation, Freehold, New Jersey, U.S.A., or the Sigma Chemical Co. Ltd, London. L-Amino acids (Ajinomoto) were obtained from Cambrian Chemicals Ltd. London; sodium L-glutamate (Ajinomoto) was obtained from B. K. Trading Co., Glasgow. Polyvinyl alcohol (Gelvatol O-6oG) was obtained from Shawinigan Ltd, London. 


\section{RESULTS}

A marker linked to penicillinase. Double auxotrophs were produced from $9945 \mathrm{~A}$ pep ade-I by the methods described, and both markers were repaired with a DNA (at non-saturating concentrations) that carried a distinctive pen allele. The cotransformation of the ade-I marker with pen was compared with the cotransformation of the other auxotrophic marker and pen in the same experiment. Cotransformation of pen with ade- $I$ and most other auxotrophs was about $0.3 \%$, indicating little useful linkage. The markers tested included $\arg F_{I}$, arg-2, trp-2, his-I, tyr-I, met-I, met-2, leu-I, ura-I and two temperature-sensitive mutants.

One mutant, however, 9945A pep ade-I ilvDI pen $I^{+} P^{+}$, showed over $2 \%$ cotransformation of $i l v D_{I}$ and pen. The nature of the lesion in this mutant was kindly determined by Dr C. Anagnostopoulos (C.N.R.S., Gif-sur-Yvette, France) as a block at the dehydrase step in isoleucine-valine biosynthesis. The cotransformation frequency of $i l v D I$ and pen was retained as the DNA concentration used in the transformation was reduced, while the cotransformation of ade-I and pen decreased. The inferred linkage between ilvDI and pen, though low, seems real, and sufficient for preliminary genetic analysis of the pen system. In contrast, cotransformation of pep with most markers was variable up to $10 \%$ but decreased as the DNA concentration was lowered.

As in the related organism, Bacillus subtilis, the ilvD locus is located near the end of the replication map and is linked to ilvA, met and thy loci (Dubnau, Goldthwaite, Smith \& Marmur, 1967), mutants in these three loci were isolated and tested for cotransformation with pen and/or ilvD. The ilvA and ilvD loci were about $60 \%$ cotransformed, and the results of a three-point cross suggest the order ilvD-ilvA-pen. A cotransformation frequency of 2 to $5 \%$ for pen with ilvA was obtained at non-saturating DNA concentrations. The met-I markers showed $15 \%$ cotransformation with $i l v D$ but there was no apparent linkage to pen. The strain met-3ilv-3, obtained by hydroxylamine treatment of spores, behaves as a met ilv $D$ double mutant, but these lesions have not been reverted either singly or together, nor separated by recombination in transformation. This strain behaves as a deletion, suggesting that met and ilv $D$ are closely linked in $B$. licheniformis.

The thy-I marker. This was made in strain 9945A pep ade-I ilvDI thy-I pen $I^{+} P^{+}$. The mutant grew on $20 \mu \mathrm{g}$ thymine $/ \mathrm{ml}$, though the medium was supplemented with $100 \mu \mathrm{g} / \mathrm{ml}$. Transformation with $0.2 \mu \mathrm{g}$ prototrophic DNA $/ \mathrm{ml}$ showed $\mathrm{I} \cdot 4 \%$ cotransfer of pen with thy-I, and and $\mathrm{I} \cdot 6 \%$ cotransfer of thy-I with $i l v D I$, but the frequency of cotransformation declined at lower DNA concentrations in both cases. The thy-I marker is not linked to ilvDI or pen, and does not seem equivalent to the thy locus in Bacillus subtilis lying between ilv $A$ and $i l v D$.

Generation of a linked marker to ilvD in transformation. By using prototrophic DNA treated with nitrous acid in transformation of 9945A pep ade- $I$ ilv $D I$, and selecting for repair of the ilv $D$ marker on a minimal medium supplemented wth nucleotides, vitamins and all the $\mathrm{L}$-amino acids except isoleucine and valine, one transformant colony was obtained which could not grow on minimal medium supplemented only with adenine. This mutant responded to tryptophan and anthranilate, and the mutation was designated trpEr (Taylor \& Trotter, 1967). Crosses with non-saturating DNA concentrations between 9945A pep ade-I trpEI pen $I^{+} P^{+}$and 9945A pep ilvDI pen IC $3 P_{22}$ (as donor) showed I I \% cotransformation of $\operatorname{trpEI}$ with $i l v D I$. In the reverse cross, $6 \%$ cotransfer was found; in neither case was cotransfer of $\operatorname{trp} E I$ with pen more than $0.2 \%$.

The trpE marker is thus linked to ilvD in Bacillus licheniformis, just as it is in B. subtilis (Dubnau et al. 1967). 
Table 2. Two-factor crosses; recombination functions as defined in the text

Each value is the result of one experiment.

Recipient strain 9945A pep, ade-I and either ilvDI or thy-I.

Pen genotypes

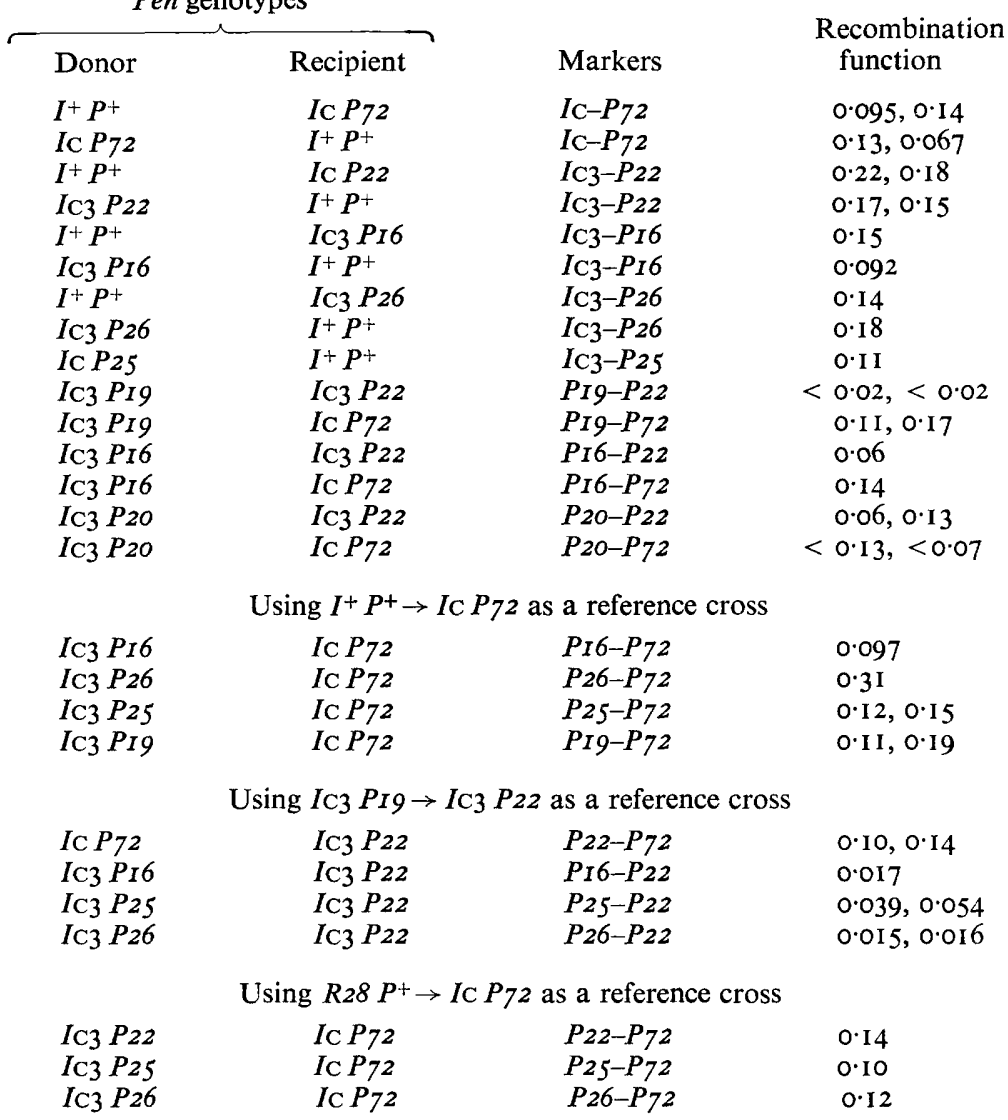

Mapping of penicillinase mutants: 2-factor crosses. Recombination values were determined where possible in crossed recipocal for the pen alleles; the transformants were, however, selected for repair of the ilvAI, ilvDI or thy-I markers in each cross. Though recombination values are variable for the same pen markers, the values do not appear to depend on which nutritional marker was repaired. In the cross $a b \rightarrow A B$, recombination values were calculated either as $A b /(a b+A b)$ or $a B /(a b+a B)$. In crosses where the donor class $a b$ resembled phenotypically one of the recombinant classes, e.g. $A b$, neither ratio can be calculated directly from observations. Since linkage to the nutritional marker selected was low, it was assumed that the frequency of each recombinant class was equal; i.e. $A b=a B$. The ratio $a B /(a b+a B)$ then equals $a B /(a b+A b)$, and $(a b+A b)$ represents all the (observable) insertions of the $b$ allele, and a recombination value can be calculated. In crosses where the donor allele is phenotypically indistinguishable from the recipient allele, but at least one of the recombinant classes, say $a B$, can be observed, a control cross was performed with the same recipient at the same time and under identical conditions with a different DNA. The proportion of transformants in the test cross carrying the donor allele $a$ is assumed to equal the proportion 
Table 3. Three-factor crosses used to determine probable marker order

\begin{tabular}{|c|c|c|c|c|}
\hline Donor & Recipient & $\begin{array}{l}\text { Relative abundance of } \\
\text { recombinant classes }\end{array}$ & $\begin{array}{l}\text { Suggested } \\
\text { order }\end{array}$ & $\begin{array}{l}\text { Recombination } \\
\text { value }\end{array}$ \\
\hline 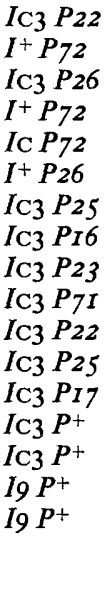 & $\begin{array}{l}I^{+} P_{72} \\
I C_{3} P_{22} \\
I^{+} P_{72} \\
I C_{3} P_{26} \\
I^{+} P_{26} \\
I C P_{72} \\
I^{+} P_{72} \\
I^{+} P_{72} \\
I^{+} P_{72} \\
I^{+} P_{72} \\
I^{+} P_{26} \\
I^{+} P_{26} \\
I^{+} P_{26} \\
I_{3} P_{22} \\
I_{C} P_{72} \\
I C_{3} P_{22} \\
I C P_{72}\end{array}$ & 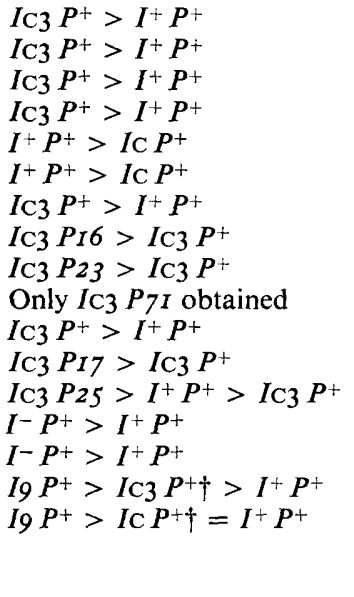 & 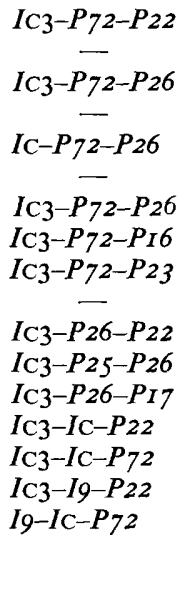 & 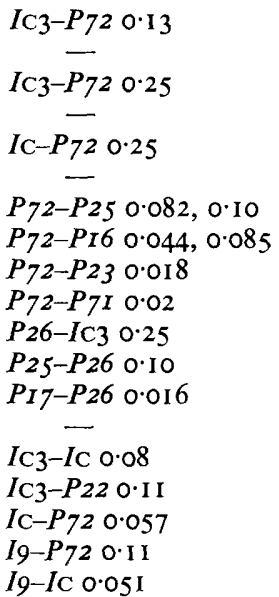 \\
\hline
\end{tabular}

* The $I^{-} P^{+}$class will include both $I_{C}$ and $I C 3$ genotypes, as well as the double mutants $I_{C} I_{C}$, unless the two mutations happen to complement each other in the same gene to give an inducible phenotype.

$\dagger$ This class probably includes IC or IC3 genotype plus I9 IC 3 or I9 Ic double mutants, unless the two mutations happen to complement each other in the same gene to give an inducible phenotype.

\section{Table 4. DNA competition experiment}

To determine whether classes of recombinants involving double crossovers could arise by incorporation of regions of DNA originating in different donor molecules. Recipient strain: 9945A AepilvaI pen $I^{+} \boldsymbol{P}_{7} 2$.

\begin{tabular}{lccc}
\multicolumn{2}{c}{ Cross } & Pen recombinants $/ 0 \cdot 1 \mathrm{ml}$ \\
Donor & Recipient & $I^{+} P^{+}$ & $I \mathrm{C} P^{+}$ \\
$I_{\mathrm{C} P 72} I_{7+P 2}$ & 0 & 0 \\
$I^{+} P^{+}$ & $I^{+} P P_{2}$ & 82 & 0 \\
$I^{+} P^{+}+I C_{C} P_{72}$ & $I^{+} P 72$ & 73 & 0
\end{tabular}

The recombinant class $I_{C} P^{+}$should only arise from a multiple transformation involving part of the $I^{+} P^{+}$ DNA and part of the IC P72 DNA.

in the control cross observed to carry $a$, so the term $(a b+a B)$ can be calculated, and the recombination value $a B /(a b+a B)$ found (Nester \& Lederberg, I96I) (see Table 2).

Three-factor crosses. Three-point crosses were used to give the probable order of pen markers and to give further recombination functions (Table 3). In some crosses, recombinants must have been the result of multiple crossover events; a DNA competition experiment (Table 4) showed that most if not all recombinants were produced from single pieces of donor DNA. This allowed ordering of the eight pen markers into a consistent order. A tentative map combining the results of the 2- and 3 -factor crosses can be produced for I4 markers; the average recombination functions shown reveal some discrepancies, though most are in agreement with the order suggested by the 3 -factor crosses (Fig. I).

Regulatory gene mutants. Five mutants derived from $749 /$ I Io had altered regulation properties, and did not have the expected phenotypes of $I$ gene mutants. Strains $749 / 1$ Io pen I 4,27 and 28 have basal levels of penicillinase similar to the wild-type strain 749 


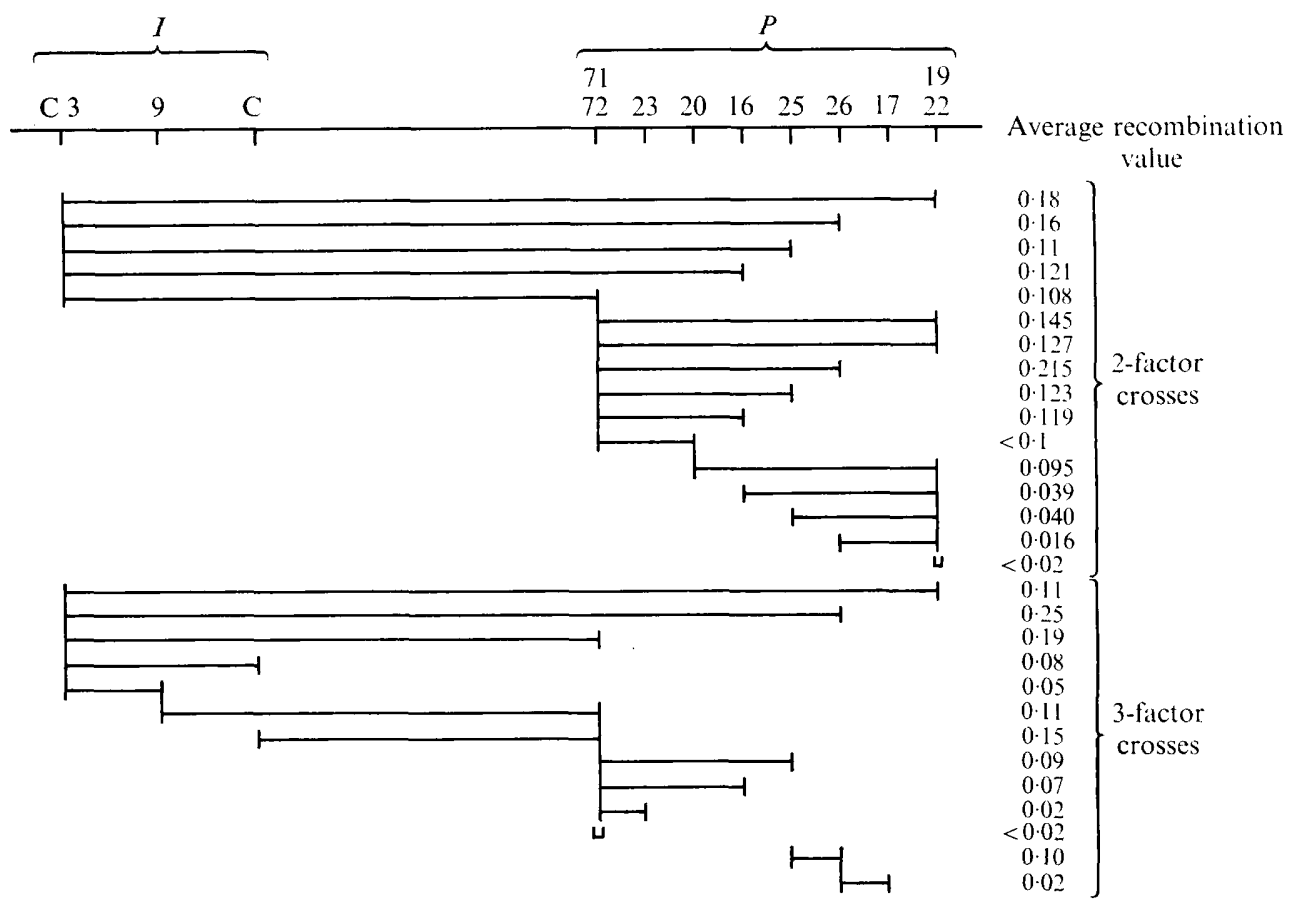

Fig. I. Tentative map of pen $I$ and $P$ mutations in Bacillus licheniformis. Based on recombination values and ordering data from 2 - and 3 -factor crosses.

Table 5. Effect of NTG mutagenesis on regulatory mutants

Results of two or three independent mutagenic treatments.

$\begin{array}{ccc}\text { Strain } & \begin{array}{c}\text { Frequency of } \\ \text { auxotrophs }\end{array} & \begin{array}{c}\text { Frequency of high-level } \\ \text { pen mutants } \\ \text { (500 to } 5000 \text { units/mg) }\end{array} \\ 749 / 1 \text { 1 } 10 \text { pen } 28 & \text { I to } 5 \% & 0.05 \text { to } 0.3 \% \\ \text { pen } 3 \mathrm{I} & 2 \text { to } 3 \% & 0.03 \text { to } 0.2 \% \\ \text { pen } 32 & 2 \text { to } 4 \% & <0.001 \% \\ \text { pen } 27 & 2 \text { to } 6 \% & 0.05 \text { to } 0.1 \% \\ 749 & 2 \text { to } 5 \% & 0.05 \text { to } 0.5 \%\end{array}$

(see Table I). On induction, however, they respond less than the wild-type (with a 50-fold increase) - respectively, with 20 -fold, 9 -fold and no increases. Strain 749/1 Io pen $3 \mathrm{r}$ has half the basal wild-type activity, and does not induce significantly. Strain 749/1 io pen 32, with ten times the activity of 749 , is also uninducible. As diploid studies are not yet possible in this organism, the effect of further mutagenesis was studied. In the wild-type, the $I$ gene is a target in which mutations with magnoconstitutive phenotypes are easily obtained; if mutagenesis of the regulatory mutants also produced magnoconstitutives at a frequency comparable with the wild-type strain, it would be a reasonable assumption that these mutants had phenotypes that were determined by the interaction of an $I$ gene product with a promoter. Table 5 shows the results of NTG mutagenesis on four of these mutants; three of them give high-level pen mutants much like the wild-type; only pen 32 produced no high-level mutants after NTG treatment. 
Table 6. Genetic crosses with strain 749/1 10 pen 28

\begin{tabular}{|c|c|c|c|}
\hline Donor & Recipient & $\begin{array}{c}\text { Class } \% \text { of } \\
P^{+} \text {recombinants }\end{array}$ & Recombination value \\
\hline$R 28 P^{+}$ & $I^{+} P 26$ & $\begin{array}{l}I^{+} P^{+} \mathrm{I} 8 \% \\
R 28 P^{+} 82 \%\end{array}$ & $R 28-P 260 \cdot 18$ \\
\hline$R 28 P^{+}$ & $\mathrm{IC}_{3} P_{22}$ & $\begin{array}{l}R 28 P+86 \% \\
I_{C} 3 P+14 \%\end{array}$ & \\
\hline $\mathrm{R}_{28} \mathrm{P}^{+}$ & $I_{C_{3}} P_{72}$ & $\begin{array}{l}R 28 P^{+} 92 \% \\
\text { IC } P^{+} 8 \%\end{array}$ & \\
\hline
\end{tabular}

Table 7. Genetic crosses with strain 749/I Io pen 27 and 749/I Io pen 14

\begin{tabular}{|c|c|c|c|c|}
\hline Donor & Recipient & Class & $\begin{array}{l}\% \text { of } P^{+} \\
\text {recombinants }\end{array}$ & $\begin{array}{l}\text { Recombination } \\
\text { value }\end{array}$ \\
\hline$R 27 P^{+}$ & $I_{\mathrm{C} 3} P_{22}$ & $\begin{array}{l}I^{-} P^{+} \\
R 27 P^{+} \\
I^{+} P^{+}\end{array}$ & $\left.\begin{array}{r}8 \cdot 9 \\
47 \cdot 8 \\
43 \cdot 3\end{array}\right\}$ & $R_{27}-\left(I \mathrm{C}_{3}, P_{22}\right) 0.55$ \\
\hline$R 27 P^{+}$ & $I_{C} P_{72}$ & $\begin{array}{l}I^{-} P^{+} \\
I^{+} P^{+} \\
R 27 P^{+}\end{array}$ & $\left.\begin{array}{l}14 \cdot 4 \\
42 \cdot 8 \\
42 \cdot 8\end{array}\right\}$ & $R 27-\left(I \mathrm{C}, P_{72}\right) 0.57$ \\
\hline$R 27 P^{+}$ & $I^{+} P 72$ & $\begin{array}{l}I^{+} P^{+} \\
R 27 P^{+}\end{array}$ & $\left.\begin{array}{l}60 \cdot 0 \\
40 \cdot 0\end{array}\right\}$ & $R 27-P 720.6$ \\
\hline$R_{4} 4 P^{+}$ & $I_{3} P_{22}$ & $\begin{array}{l}I^{-} P^{+} \\
I^{+} P^{+} \\
R I 4 P^{+}\end{array}$ & $\left.\begin{array}{r}6 \cdot 8 \\
5 I \cdot 8 \\
4 I \cdot 4\end{array}\right\}$ & $R_{14}-\left(I \mathrm{C}_{3}, P_{22}\right) 0.59$ \\
\hline$R I_{4} P^{+}$ & $I^{+} P_{72}$ & $\begin{array}{l}I^{+} P^{+} \\
R I 4 P^{+}\end{array}$ & $\left.\begin{array}{l}53 \cdot 0 \\
47 \cdot 0\end{array}\right\}$ & $R_{14}-P_{72} 0.53$ \\
\hline
\end{tabular}

(i) 749/1 Io pen 28. Data from the crosses shown in Table 6 suggest a recombination value of 0.18 between $R 28$ and $P 26$. The absence of $I^{-}$recombinants in both the second and third crosses suggests that $R 28$ is close to IC and IC3. One of the high-level mutants obtained from pen 28 by NTG treatment contained a second mutation (IRVI) separable from $R 28$ by recombination, but the apparent mapping order $(R 28-I \mathrm{RVI}-P 26)$ and recombination values were not considered to locate $R 28$ necessarily in the $I$ gene itself.

(ii) 749/I Io pen $3 \mathrm{I}$. This uninducible strain was crossed with each of four recipient strains, but of 205 pen recombinants with the basal penicillinase level like that of pen $3 \mathrm{I}$, all were inducible. 28 penicillinase-positive recombinants were obtained in a cross with $P_{72}$, but none had wild-type $P^{+}$characteristics. It is concluded that there is a mutation $\left(P_{3 I}\right)$, probably close to $P_{72}$ in the structural gene producing penicillinase with about half the specific activity of the wild-type enzyme. The loss of inducibility could be related to $P_{3 I}$ itself, in which case this phenotype is only apparent in strain 749 and not in 9945A; alternatively, and more probably, there could in addition be a regulator mutation $\left(R_{3} I\right)$, either unlinked to $P_{3 I}$, or transferred in some of the recombinants but unexpressed in strain 9945A. Further analysis of this mutant is required.

(iii) 749/I Io pen 27 and 749/I Io pen I4, which do not induce as well as the wild-type 749, both behave as point mutants (R27 and $R 14$ ) weakly linked to P72 (Table 7). If the phenotypes of $I_{\mathrm{C}} 3 R_{27} P^{+}, I_{\mathrm{C}} R_{27} P^{+}$and $I_{\mathrm{C}} R_{14} P^{+}$are magnoconstitutive (as seems likely from the NTG mutagenesis experiments), there appears to be weak linkage also between $R 27$ and IC3 or $P 22$ ( 0.55 recombination value) and $R 27$ and $I C$ or $P 22$ (0.57 recombination value); similarly, between $R_{14}$ and $I_{C 3}$ or $P_{22}(0.59$ recombination value). It is not possible to 
Table 8. Genetic crosses with 749/110 pen 32

The $R 32$ classes may include either $I$ allele.

\begin{tabular}{|c|c|c|c|}
\hline Donor & Recipient & $\begin{array}{l}P^{+} \text {recombinant } \\
\text { classes }\end{array}$ & $\begin{array}{l}\text { Recombination } \\
\text { function }\end{array}$ \\
\hline $\begin{array}{l}R_{32} P^{\dagger} \\
R_{32} P^{+}\end{array}$ & $\begin{array}{l}I_{3} P_{22} \\
I^{+} P_{72}\end{array}$ & $\begin{array}{l}R_{32} P^{+}>I^{+} P^{+}>I \text { C3 } P^{+} \\
R_{32} P^{+}>I^{+} P^{+}\end{array}$ & $\begin{array}{l}R_{32}-P_{22} \\
R_{32}-P_{72}\end{array}$ \\
\hline$R_{32} P^{+}$ & Iс $P_{72}$ & $R_{32} P^{+}>I \mathrm{C} P^{+}$ & $R_{32}-P_{72} 0.19$ \\
\hline
\end{tabular}

determine on which side of $I-P R 27$ and RI4 lie; however, it seems probable that they are located in a different gene to $I$, and possibly together. The strains producing high levels of penicillinase after NTG treatment of pen 27 behave in crosses as though they have an $I$ mutation, separable from the $R 27$ mutation, confirming the active role of the $I$ gene product in the expression of penicillinase in this mutant.

(iv) 749/1 Io pen 32. This uninducible strain has not been mutagenized by NTG to give strains producing high levels of penicillinase at a significant frequency $\left(\geqslant \mathrm{I} / \mathrm{I} \mathrm{O}^{5}\right)$. Expression of the structural gene is unlikely to be affected by the integrity of the $I$ gene therefore. Genetic crosses (Table 8) show that the marker order is $I_{\mathrm{C}}-I_{\mathrm{C}}-P_{72}-P_{22}-R_{32}$. The enzyme produced is apparently normal (Dubnau \& Pollock, I965). On the Jacob-Monod hypothesis (I96I) this regulatory gene can be ascribed an operator function, which would account for the lack of response of the strain under conditions that should have generated $I$ gene mutants.

\section{DISCUSSION}

After tests with a variety of markers, ilv $D$ and $i l v A$ were the two showing the best linkage to pen in transformations. By selecting for the repair of these markers, and/or of thy-I, enough pen transformants were obtained for a limited genetic analysis of the system. No closer markers have been found; ilv $A$ is a terminal marker on the replication map of Bacillus licheniformis (Tyeryar, Lawton \& MacQuillan, 1968) and pen seems distal to it. The thy marker, which in $B$. subtilis lies between $i l v A$ and $i l v D$, has not been found to be linked to these markers or pen in $B$. licheniformis. Two- and 3 -factor crosses have established a tentative map for I 4 mutations in the closely linked $I$ and $P$ genes in this system. The structural gene mutants mapped either close to or between $P_{22}$ and $P_{72}$, both of which have no detectable penicillinase activity but produce immunologically cross-reacting proteins. Other mutants classified as structural gene mutants had measurable penicillinase activity but abnormal enzymological or immunological properties $\left(P_{16}, P_{19}, P_{20}, P_{23}\right.$ and $P 7 I$ ) and were probably missense mutants. Other structural gene mutants with little activity and giving no test for cross-reacting material may be nonsense mutations, since their activity, $0.0 \mathrm{I}$ to $0.05 \%$ of parental activity, is similar to the level of expression of nonsense mutations in other systems (Garen \& Siddiqi, 1962; Gorini, Jacoby \& Breckenridge, I966) and some of these mutations show in addition other properties of nonsense mutations such as phenotypic and genotypic suppression (Collins \& Sherratt, in preparation). In the $I$ gene, closely linked to the structural gene as shown by Dubnau \& Pollock (1965), are mutations giving magnoconstitutive phenotypes (Collins et al. 1965), a temperature-dependent inducible phenotype and possibly one $(R 28)$ giving a super-repressed phenotype. Such mutations have been described in the $\beta$-galactosidase (Jacob \& Monod, I96I) and other systems where a repressor is produced. It is not yet possible to test dominance relationships 
in diploids in this organism, but in Staphylococcus aureus where diploids can be constructed containing two pen alleles, $I^{-}$mutants are recessive to the $I^{+}$alleles (Richmond, $1965 b$; 1966 ).

749/1 Io pen 27 and 749/I Io pen I 4 are poorly inducible, and the mutations R27 and RI4 may not lie in the $I$ gene, since they are only about $50 \%$ cotransformed with the $I$ and $P$ genes. The inducible phenotype of $R 27$ is not observed in the presence of $I$ mutations which give an overall magnoconstitutive phenotype. The gene product of $R_{27}$ (and $R_{4} 4$ if it is allelic) must therefore be involved in the chain of events leading to induction of penicillinase at a stage before the interaction of repressor and gene.

The uninducible phenotype of 749/I I o pen 3I has not been successfully transferred into strain $9945 \mathrm{~A}$. A structural gene mutation with lowered penicillinase activity is transferred easily from this strain; since the genetic background of 749 and 9945A may contain unknown differences, the expression of a mutation in one strain may differ from its expression in the other. This could be the case if $P_{3 I}$ is the only mutation present, or if there were some other regulatory gene mutation $\left(R_{3} I\right)$ as well. The pen $3 I$ phenotype could of course be the result of a number of mutations which have a low probability of being transferred together in transformation.

\section{The orientation of the $I$ and $P$ genes: the nature of $R_{32}$}

The $R_{32}$ mutation isolates expression of the structural gene from the control by the $I$ gene product. It thus behaves as an operator mutation in this respect, though unlike an $0^{\circ}$ mutation there is no residual inducibility. The level of expression is $5 \%$ of a magnoconstitutive level and it appears that the ability of the structural gene to be expressed has been modified by $R_{32}$. Some evidence suggesting that $R_{32}$ could be a deletion fusing the pen genes to a neighbouring operon is presented in another paper (Collins \& Sherratt, in preparation). The orientation of the pen genes may be represented $O-P-I$, with weak linkage to a regulator function (containing R27 and RI4) which could be on either side. Preliminary protein sequence studies suggest the $C$ terminal of the enzyme is close to $P_{72}$ and $P_{7 I}$, confirming this orientation (L. Kelly, unpublished). The operator in this position might also serve the $I$ gene in a single operon; repressor synthesis would then be under its own control. This possibility is being further studied.

\section{A model for penicillinase regulation (Fig. 2)}

From the physiological evidence three components seem to be the minimum required for penicillinase transcriptional regulation. The penicillin-binding component may be the site at which the primary interaction of the inducer with the cell takes place; the genetic repressor limits expression of the structural gene for penicillinase and there could be a component acting as an endogenous inducer or corepressor and linking the primary event to the removal of the genetic repressor. The genetic evidence in the case of Staphylococcus aureus (Cohen \& Sweeney, I965; Richmond, 1967; Richmond \& Smith, 1967; Smith, 1968) suggests that there are at least three regulatory loci, and in Bacillus licheniformis there seem to be at least two regulatory loci. Equivalence of the physiological components and the genetic loci is not easy to make: the $I$ gene product appears to be the genetic repressor, however. Penicillin-binding studies (J. Davies, unpublished) have not revealed any significant differences between any of the regulator mutants and the wild-type; it does not seem that any mutants defective in penicillin-binding are included in the set studied. The $R 28$ mutation could be in the $I$ gene, producing a repressor with altered response to the normal cellular effector. Mutations such as $R 27$ and $R I 4$ could affect the affinity or the amount of the efiector binding to the repressor, if there is an endogenous inducer or corepressor 


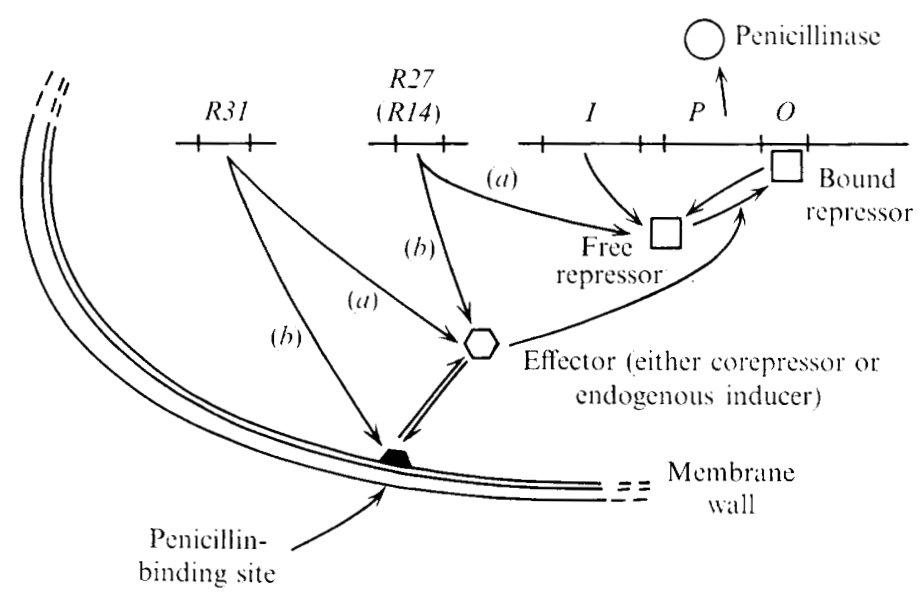

Fig. 2. A model for penicillinase regulation. Control of penicillinase synthesis is exerted through a repressor, which is a protein coded in gene $I$ and possibly also in the regulation region $R 27$ (and RI4). Repression is either aided or antagonized by the effector, itself genetically determined ( $R 27$ or $R_{3} I$, perhaps), and whose concentration is affected by events such as penicillin attachment to the penicillin binding site. The alternative roles of $R_{27}$ and $R_{3} I$ are indicated $(a)$ and $(b)$.

present. Alternatively, the product of this $R$ gene could form part of the active repressor complex, in a manner that has been suggested for the staphylococcal system (Richmond I965a).

The process of penicillinase induction would involve the concentration of the intracellular effector altering after penicillin-binding at the surface site, the concentration of this effector determining the level of expression of the structural gene. The manner in which penicillin binding alters the effector concentration is not known, though changes in pool levels of cell wall mucopeptides precursors are found (Park, I952 a, b, $c$; Ito \& Saito, 1963). These are unlikely to be intracellular inducers as they also accumulate after inhibition of cell wall synthesis by antibiotics which do not induce penicillinase.

The pen 3I phenotype could be due to a modification of effector synthesis making it insensitive to the primary induction event at the cell surface - which would make the strain uninducible; the production of the same effector in strain 9945A might have a different control mechanism. The presence of such an intermediate component between the primary site of interaction of the inducer at the cell surface and the repressor bound on the DNA, whose concentration determined the extent of repressor binding and in turn the expression of the structural gene could lead to slow responses in induction and repression observed.

The pen $3 \mathrm{I}$ phenotype could alternatively arise if the penicillin-binding site were affected not in its penicillin-binding capacity but in its ability to interact with the intracellular effector. The equivalent regulatory mutants in Staphylococcus aureus have been reported (Cohen \& Sweeney, 1968) and also have abnormal physiologies; if the penicillin-binding site is the enzyme found by Strominger \& Lawrence (1969) to catalyse the transpeptidase reaction in mucopeptide formation, mutations affecting its properties, if not lethal, would certainly be expected to produce altered growth properties.

A model advanced for the regulation of penicillinase synthesis in Bacillus cereus by Csanyi (Csanyi, Jacobi \& Straub, 1967) also utilizes two components, the penicillin-binding site and a factor which when activated stabilizes the penicillinase messenger. The penicillinase messenger is supposed to be produced at all times at a constant rate. Interpretation of the 
data for $B$. licheniformis in terms of this model seems difficult, since measurements of the apparent half-life of the penicillinase messenger show it to be in the region 2 to 4 min both in induced and uninduced cells (Davies, I969a,b).

In the absence of diploids in this organism, further analysis of the role of the different regulatory gene functions is rendered difficult. The complexity of the system in Bacillus licheniformis is now established, however, and the likely relationship to the staphylococcal system extends beyond the known similarities in the amino acid sequences of the penicillinases (Ambler \& Meadway, 1969) to the likely arrangement of the regulatory genes.

We would like to thank the MRC for the award of a training scholarship to one of us (D.J.S.). We would also like to thank Miss Fiona Crawford for her excellent technical assistance.

\section{REFERENCES}

COHEN, S. \& SWEeney, M. H. (1968). Constitutive penicillinase formation in S. aureus owing to a mutation unlinked to the penicillinase plasmid. Journal of Bacteriology 95, I368-1374.

COLlins, J. F. \& KornBerg, H. L. (1960). The metabolism of $\mathrm{C}_{2}$ compounds in microorganisms. Biochemical Journal 77, 430-438.

Collins, J. F., Mandelstam, J., Pollock, M. R., Richmond, M. H. \& Sneath, P. H. A. (1965). A suggested phenotypic classification and terminology for enzyme mutants in microorganisms. Nature, London 208, 84I-843.

CSANYI, V., JACOBI, G. \& Straub, B. F. (1967). The regulation of penicillinase synthesis. Biochimica et biophysica acta I45, 470-484.

Curtiss, R., Charamella, L. J., Berg, C. M. \& Harris, P. E. (1965). Kinetic and genetic analysis of D-cycloserine resistance in E. coli. Journal of Bacteriology 9o, $1238-1250$.

DaviES, J. W. ( $196 \mathrm{c} a$ ). Regulation of penicillinase synthesis in Bacillus licheniformis: Binding of inducer to cells, and the half-life of the messenger ribonucleic acid. Biochemical Journal n15, 44 P.

Davies, J. W. (I969b). The stability and cell content of pencillinase messenger RNA in Bacillus licheniformis. Journal of General Microbiology 59, 17 I-184.

Dubnau, D., Goldthwaite, C., Smith, I. \& Marmur, J. (1967). Genetic mapping in B. subtilis. Journal of Molecular Biology 27, 163-185.

Dubnau, D. \& Pollock, M. R. (1965). The genetics of Bacillus licheniformis penicillinase; a preliminary analysis from studies on mutation and inter-strain and intra-strain transformations. Journal of General Microbiology 4r, 7-2I.

DuthiE, E. (1947). The production of stable potent preparations of penicillinase. Journal of General Microbiology I, 370-377.

GAREN, A. \& SidDieI, O. (I962). Suppression of mutations in the alkaline phosphatase structural cistron of E. coli. Proceedings of the National Academy of Sciences of the United States of America 48, I I 2 I-I I 27.

Geronimus, L. \& COHEN, S. (1957). Induction of staphylococcal penicillinase. Journal of Bacteriology 73, $28-34$.

Gorini, L., JACoby, G. \& Breckenridge, L. (1966). Ribosomal Ambiguity. Cold Spring Harbor Symposium on Quantitative Biology 31, 657-664.

ITo, E. \& SAITo, M. (1963). Time course of accumulation of UDP- $N$-acetylamino sugar derivatives in Staphylococcus aureus. Biochimica et biophysica acta 78, 237-247.

JACOB, F. \& MONOD, J. (I96I). Genetic mechanisms in the synthesis of proteins. Journal of Molecular Biology 3, 3I $8-356$.

MARMUR, J. (1961). A procedure for the isolation of DNA from microorganisms. Journal of Molecular Biology 3, 208-218.

Nester, E. W. \& Lederberg, J. (I96I). Linkage of genetic units of $B$. subtilis in DNA transformation. Proceedings of the National Academy of Sciences of the Unites States of America 47, 52-55.

OKada, T., Homma, J. \& Sonohara, H. (I962). Improved method for obtaining thymineless mutants of E. coli and S. typhimurium. Journal of Bacteriology 84, 602-603.

PARK, J. T. (1952a). Uridine-5'-pyrophosphate derivatives. I. Isolation from Staphylococcus aureus. Journal of Biological Chemistry 194, 877-884. 
PARK, J. T. (1952b). Uridine- 5 -pyrophosphate derivatives. II. A structure common to three derivatives. Journal of Biological Chemistry 194, 885-896.

PARK, J. T. (I952c). Uridine-5'-pyrophosphate derivatives. III. Amino-acid containing derivatives. Journal of Biological Chemistry 194, 897-904.

Perret, C. J. (1954). Iodometric assay for penicillinase. Nature, London 174, 1012-IOI 3.

Pollock, M. R. (1950). Penicillinase adaptation in B. cereus: adaptive enzyme formation in the absence of tree substrate. British Journal of Experimental Pathology 3I, 739-753.

Pollock, M. R. (1960). Penicillinase. In The Enzymes, vol. 4, pp. 269-273. Edited by P. D. Boyer, H. Lardy and K. Myrback. New York: Academic Press.

Pollock, M. R. (1964). Stimulating and inhibiting antibodies for bacterial penicillinase. Immunology 7, 707-723.

RichmoND, M. H. (1965a). Wild-type variants of exopenicillinase from Staphylococcus aureus. Biochemical Journal 94, 584-593.

Richmond, M. H. (1965 b). Dominance of the inducible state in strains of $S$. aureus containing two distinct penicillinase plasmids. Journal of Bacteriology 90, 370-374.

RICHMOND, M. H. (I966). The genetic constitution of certain penicillinase micromutants in Staphylococcus aureus. Journal of General Microbiology 45, 5I-60.

RichmOND, M. H. (1967). A secondary regulatory region involved in penicillinase synthesis in $S$. aureus. Journal of Molecular Biology 26, 357-360.

Richmond, M. H. \& SMith, K. (1967). Regulation of penicillinase synthesis in Staphylococcus aureus. Proceedings of the VII Congress of Biochemistry, Tokyo, 255.

SмIтн, K. (1968). Constitutive mutations in the penicillinase system of S. aureus. Ph.D. Thesis, University of Edinburgh.

TAYLOR, A. L. \& Trotter, C. D. (1967). Revised linkage map of E. coli. Bacteriological Reviews 3r, 332-353.

TESSMAN, I. (1968). Mutagenic treatment of double- and single-stranded DNA phages $\mathrm{T}_{4}$ and $\mathrm{S}_{13} 3$ with hydroxylamine. Virology 35, 331-333.

Thorne, C. B. \& Stull, H. B. (1966). Factors affecting transformation in B. licheniformis. Journal of Bacteriology 91, 101 2-1020.

Tyeryar, F. J., LAWTON, W. D. \& MACQuillan, A. M. (I968). Sequential replication of the chromosome of B. licheniformis. Journal of Bacteriology 95, 2062-2069. 